\title{
STATUS OF GANGES DOLPHIN, PLATANISTA GANGETICA GANGETICA (ROXBURGH, 1801) IN THE RIVER BURIGANGA, DHAKA
}

\author{
Shayer Mahmood Ibney Alam, Md. Muzammel Hossain*, Mohammad Abdul Baki \\ and Naser Ahmed Bhouiyan \\ Department of Zoology, Jagannath University, Dhaka 1100, Bangladesh
}

\begin{abstract}
Population abundance and density of the Ganges River Dolphin Platanista gangetica gangetica (Roxburgh, 1801) was studied in the Buriganga River from December 2012 to November 2013.The survey was conducted twice a month. The dolphins were counted directly and applied in transect length of 10.5 $\mathrm{km}$ within $15 \mathrm{~km}$ stretches of the river. A total of 34 sightings of dolphins were recorded both in individuals and groups. We encountered the dolphins at the rate of 0.48 dolphins per $\mathrm{km}$ in the Buriganga River. Highest best-high-low estimate of 12-14-10 individuals were recorded in November 2013. The mean density was 0.38 (SD \pm 0.37 ) dolphins $/ \mathrm{km}^{2}$ with the highest density of dolphin observed also in the month of November, which was 1.14 dolphin $/ \mathrm{km}^{2}$. Pollution and water traffic were observed to be the major threats to the dolphins.
\end{abstract}

Key words: Ganges River Dolphin, Buriganga River, Density, Encounter rate.

\section{INTRODUCTION}

Bangladesh is known to be a riverine country with more than 700 rivers. Most of these rivers are under four major river systems - the BrahmaputraJamuna, the Ganges-Padma, the Surma-Meghna, and the Chittagong Region river system (Alam and Chowdhury 2012) all of which are known to be occupied by the globally threatened species the Ganges River Dolphins Platanista gangetica gangetica (Anderson 1878, Kasuya and Haque 1972, Haque 1976, Jones 1982, Mohan 1989, Reeves and Brownell 1989, Shrestha 1989, Reeves et al. 1993, Smith et al. 1998, Ahmed, 2000, Smith et al. 2001 and Smith et al. 2012).

Platanista gangetica is an endangered species as per IUCN global redlist (Smith et al. 2012), is on appendix I of the CITES (CITES 2013) and is also listed in appendix II of CMS (CMS 2012). Modification of river flows (especially from dams), alterations in sediment and nutrient fluxes, habitat destruction, river pollution from urbanization and agriculture, boat traffic, illegal intentional hunting, and over exploitative fisheries are known to threaten the habitats of this species in South Asia (Payne and Temple 1996, Bannerjee 1999, Dudgeon 2000a, 2000b, 2005; Manel et al. 2000, Gergel et al. 2002). In Bangladesh, however, habitat fragmentation by barrages, excessive water abstraction and river pollution are the major threats for this species (Smith and Smith 1998, Smith et al. 1998, Sinha 2006, and Alam and Sarker 2012). Hence,

\footnotetext{
*Author for correspondence: <muzammel3@gmail.com>.
} 
they are classified as an endangered species in the country (IUCN Bangladesh 2000) and are placed in the First Schedule of Bangladesh Wildlife (Preservation \& Security) Acts, 2012.

Ganges River Dolphins are present in the Buriganga River, which is mostly a polluted river in Bangladesh with huge industrial, household discharges, encroachments and vehicle loads and sometimes regarded as ecologically dead (IWM 2004, Ahmed and Reazuddin 2000, Smith et al. 2008, Alam and Sarker 2012). Over the last decade, this pressure on the ecosystem increased in many ways from increasing numbers of industries to vehicles carrying both humans and goods (Islam 2011).

Ganges River Dolphin is the apex predator in the river system where it lives (Klinowska 1991, Culik 2003). Therefore, their numbers are always low and can be a good indicator of the health of the aquatic ecosystem where they live (Gómez-Salazar 2012). They usually travel alone or in small groups, but as many as 3 to 10 individuals have also been observed feeding in the same river section (Smith 1993). Smith et al. (1998) conducted a short visit to the Buriganga River to survey the status of the Ganges River Dolphins, where they observed only one group of two to three individuals. Later, Alam and Sarker (2012) conducted a month-wise yearlong study during 2003-2004 where they found a population ranging from none to 9 in different months in full stretch of this river (Basilla to Hariharpara in Fatulla). Since then, no study has been reported and the present study was conducted from Babu Bazar Bridge to Amin Bazar Bridgeto observe the status of dolphin population in the present condition of river Buriganga.

\section{MATERIAL AND METHODS}

Study area: Buriganga River is located in the south-western periphery of Dhaka City and the river is $17 \mathrm{~km}$ long with an average depth of 25 feet $(7.6 \mathrm{~m})$ and maximum depth of 58 feet $(18 \mathrm{~m})$. The river is under intense anthropogenic pressures caused by urban occupation of the surrounding areas and by the use of the water body, which has generated problems with water pollution and destruction of the margins (Ahmed and Reazuddin 2000). The study area was started from Babu Bazar bridge $\left(23^{\circ} 42^{`} \mathrm{~N} 90^{\circ} 24^{`} \mathrm{E}\right)$ to ending point Amin Bazar bridge ( $23^{\circ} 47^{\circ} \mathrm{N} 90^{\circ} 20^{\prime} \mathrm{E}$ ).

Data collection and calculation: Data were collected during boat-based surveys conducted by direct observation from December 2012 to November 2013 along the $15 \mathrm{~km}$ in the river Buriganga. The survey design principles followed those used in previous studies conducted by different authors (Shrestha 1989; Smith et al. 1994, Chaudhary 2007 and Alam and Sarker 2012). A boat based survey method and distance sampling were used to obtain density and encounter rate of dolphins. Two surveys used to be conducted per month, except November 2013. In November 2013, surveys were performed four times per week 
due to more sightings compared to other months. Direct count method was used (Smith et al. 1994, Sinha and Sharma 2003) to estimate the population. Density and Encounter Rates were measured using a distance of $10.5 \mathrm{~km}$ within the study area where the dolphins were recorded.

\section{RESULTS AND DISCUSSION}

Population status: A total of 24 boat-based survey trips were counted for making the dolphin estimates within the study area. During the study period about 164 hours have been spent for surveys in the study area. This study were recorded a total of 34 sightings during the study period and a best-high-low estimate 12-14-10 in November 2013 in the river from Babu Bazar to Amin Bazar Bridge. Alam and Sarkar (2012) reported a total of 29 sightings with the highest of five sightings and a best-high-low estimate of 9-11-7 individuals in Buriganga River (Basilla to Hariharpara) in November 2004. This variation may be due to the difference in sampling design and area. However, in Bangladesh, 55 sightings were recorded from Sundarbans Delta area in March 2002 (Smith et al. 2006) and 25 sightings were recorded from Jamuna River in just three days in April, 1996 (Smith et al. 1998). Best-high-low estimate of 25-30-21 individuals were recorded in the Karnali River, Nepal (Smith 1993).

Number: A total of 34 sightings of dolphins were recorded both in individuals $76 \%$ and in groups $24 \%$. Only five times in different sites they were observed in groups, composition of which varied from 2 to 4 individuals. Best-high-low estimates and ranges in different months during the study period are provided in Fig. 2. Maximum number of dolphins was observed in the month of November with best-high-low estimate of 12-14-10, followed by October with 10-12-8 individuals (Fig. 1). Maximum range of number of dolphins was 12 also in the month of November 2013. Dolphin was not observed in August and September in the study area. Maximum numbers of sightings were also during the months of October and November which was 5 on each month with mean group size of 2.4 and 2.8 (total no of dolphin/total sighting no.) respectively. Mean group sizes in different months are given in Table 2.

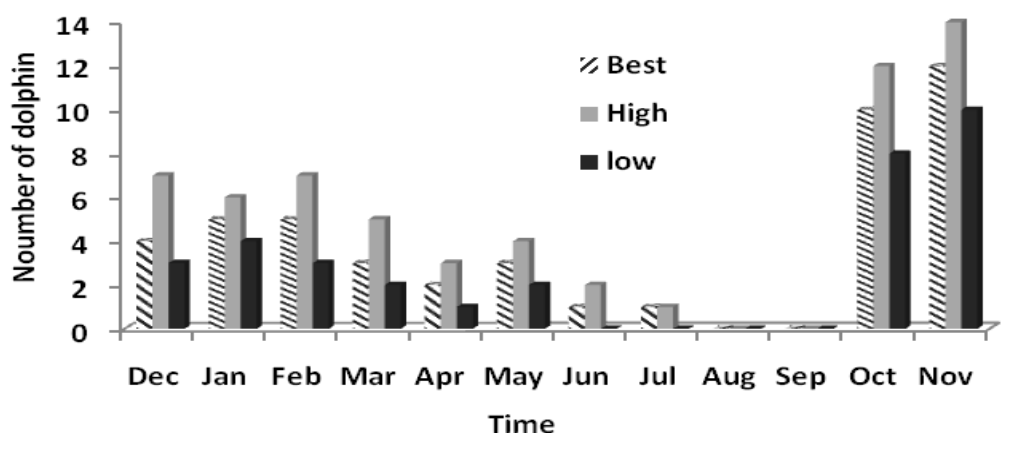

Fig. 1. Monthly best-high-low estimates of Ganges River Dolphins in the Buriganga River 
Density and Encounter rate: The stretch of Kholamora $\left(23^{\circ} 43^{\prime} \mathrm{N} 90^{\circ} 22^{\prime} \mathrm{E}\right)$ to Amin Bazar bridge $\left(23^{\circ} 47^{\circ} \mathrm{N} 90^{\circ} 20^{\circ} \mathrm{E}\right.$ ) in Buriganga River (approx. $10.5 \mathrm{~km}$ ) was chosen for estimating the density and encounter rate during the study period instead of the whole stretch of the river under the study area (approx. 15 $\mathrm{km})$. This is because of the absence of any dolphin from Babu Bazar Bridge $\left(23^{\circ}\right.$ $\left.42^{\prime} \mathrm{N} 90^{\circ} 24^{\prime} \mathrm{E}\right)$ to Kholamora Ghat $\left(23^{\circ} 43^{\prime} \mathrm{N} 90^{\circ} 22^{\prime} \mathrm{E}\right)$ throughout the study period. Therefore, this zone is the place within the study area where dolphins were found. Monthly density and encounter rates are given in Fig. 2 and Fig 3. The mean density of the dolphins was $0.38 \pm 0.37$ dolphins $/ \mathrm{km}^{2}$ in the river. The highest density of dolphins was observed at the month of November (1.14 dolphins $/ \mathrm{km}^{2}$ ) and minimum in month of August and September 2013 (0.0 dolphin $/ \mathrm{km}^{2}$ ) (Fig. 2). Alam and Sarkar (2012) found the mean density was 0.25 dolphins $/ \mathrm{km}^{2}$ in the Buriganga River (Basilla to Hariharpara) in 2003-2004. A survey in the Koshi River, Nepal (a range of $38 \mathrm{~km}$ ) during October 2006 and January 2007 indicated a density of 0.39 dolphins $/ \mathrm{km}^{2}$ (Chaudhary 2007).

Table 1. Density of dolphins in different Rivers.

\begin{tabular}{lccl}
\hline \multicolumn{1}{c}{ Name of water body } & $\begin{array}{c}\text { Year of } \\
\text { data } \\
\text { collection }\end{array}$ & $\begin{array}{c}\text { Density } \\
(\text { dolphins } / \\
\left.\mathrm{km}^{2}\right)\end{array}$ & References \\
\hline Babitonga Bay, Southern Brazil & $2002-2003$ & $1.6,1.2,1.3$ & Marta 2011 \\
Banana River in summer, Florida & $2002-2004$ & 0.58 & Durden 2005 \\
$\begin{array}{l}\text { Northern Indian River in summer, } \\
\text { Florida }\end{array}$ & $2002-2004$ & 0.49 & Durden 2005 \\
$\begin{array}{l}\text { Southern Indian River in summer, } \\
\text { Florida }\end{array}$ & $2002-2004$ & 0.29 & Durden 2005 \\
$\begin{array}{l}\text { Buriganga River, Bangladesh } \\
\text { (Southern part) }\end{array}$ & $2002-2003$ & 0.25 & Alam and Sarkar \\
$\begin{array}{l}\text { Buriganga River, Bangladesh } \\
\text { (Northern part) }\end{array}$ & $2012-2013$ & 0.38 & 2012 \\
\hline
\end{tabular}

In Babitonga Bay, Southern Brazil, Banana River in Florida and Northern Indian River, Florida the density of river dolphins were 1.6, 0.58 and 0.49 individuals $/ \mathrm{km}^{2}$ (Table 1 ). 


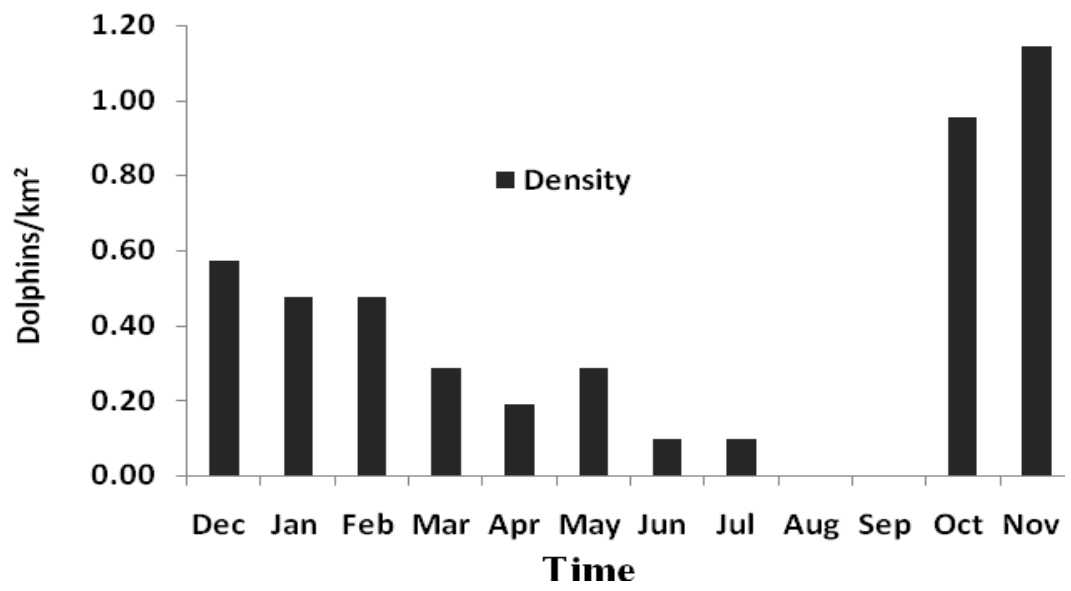

Fig. 2. Monthly Density rate of Ganges River Dolphins in the Buriganga River

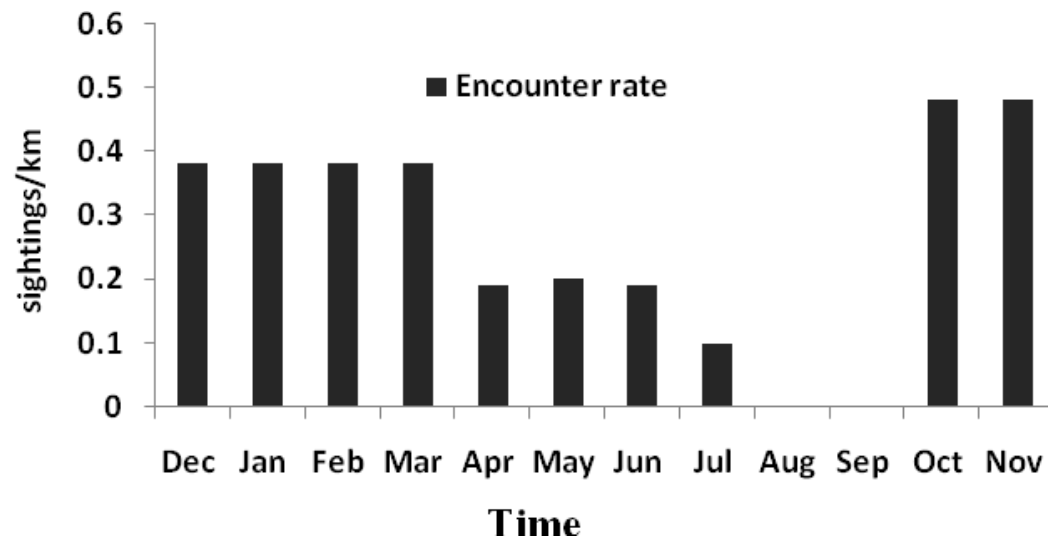

Fig. 3. Monthly encounter rate of Ganges River Dolphins in the Buriganga River

In the present study the highest encounter rate of dolphins was 0.48 sightings $/ \mathrm{km}$ in November $2013(10.5 \mathrm{~km})$ while the minimum encounter rate in the month of August and September 2013 (0.0 sighting/km)(Fig 3); while it was 0.29 sightings $/ \mathrm{km}$ in November $2004(17 \mathrm{~km})$ in the Buriganga River by Alam and Sarkar (2012). Dolphin encounter rate in the Brahmaputra River was 0.24 sightings/km (Wakid and Braulik 2009). During October 1995 and April 1996 in sections of the Jamuna $(189.6 \mathrm{~km})$ and Kushiyara Rivers $(113.0 \mathrm{~km})$, dolphins were encountered at rate of 0.13 and 0.08 sightings $/ \mathrm{km}$, respectively (Smith et al. 1998). While the present study found 0.48 and 0.19 sighting $/ \mathrm{km}$ in October and April respectively (Fig. 3). In the Karnaphuli-Sangu river complex and the lower Sangu of Bangladesh, the encounter rate was 0.76 and 1.36 dolphins $/ \mathrm{km}$ respectively (Smith et al. 2001). The results show that the density and encounter 
rate of the dolphins have increased, but in reality, Alam and Sarkar (2012) studied in the whole of Buriganga River $(17 \mathrm{~km})$ with some parts of river Dhaleshwari and the present study included only the northern part of the Buriganga River extended to some parts of River Turag (total $10.5 \mathrm{~km}$ ). The differences in length and width of the river might have been the factor influencing this increase in density. However, further detailed studies are necessary to identify the factors.

Distribution: Dolphins were observed randomly within 6 locations in the study area during the study period (Fig. 4). Locations where dolphins were observed are: $\mathrm{B} 1=$ Babubazar to kholamora $(4.5 \mathrm{~km}), \mathrm{B} 2=$ Kholamora to Madhachor $(1.5 \mathrm{~km}), \mathrm{B} 3=$ Madhachor to Basilla bridge $(2 \mathrm{~km}) ; \mathrm{C} 1=$ Basilla bridge to Sholmasi $(2 \mathrm{~km}), \mathrm{C} 2=$ Sholmasi to Barobordasi $(2.5 \mathrm{~km})$ and $\mathrm{C} 3=$ Barobordasi to Amin bazar bridge $(2.5 \mathrm{~km})$ in the Buriganga River.

B1 site length was $4.5 \mathrm{~km}$. No dolphin was observed in B1 site during the study period. Maximum numbers of dolphins were observed in site B3 and C1 which were 4 and 5 with densities of 2 and 2.5 dolphins $/ \mathrm{km}^{2}$ respectively in November 2013 (Table 2). C3 site maximum numbers of 3 dolphins were observed at December 2012. B2 site maximum numbers of 4 dolphins were observed at October, C2 site maximum numbers of 3 dolphins were observed at November 2013 in the Buriganga River (Table 2).

The Ganges River Dolphins were once abundant and used to be seen almost everywhere throughout the study area as known from local people. During the study, the dolphins were to be restricted to a few locations with multiple sightings in different visits (Fig. 4 and Table 2). Preliminary survey confirmed about the presence and absence areas of dolphins in that section of the river. This was also supported by Alam and Sarker (2012). The absence of dolphin in the area due to, may be, the human population along the river bank seemed to exert immense pressure from Babu bazzar bridge to Kholamora ghat (appox. 4.5 $\mathrm{km}$.), water pollution caused by dumping of industrial, medical as well as household wastes, transportations (foods, plastic and oil thrown into the water).

Table 2. Monthly sighting and mean group size of Ganges river dolphin estimate in the River Buriganga

\begin{tabular}{cccccc}
\hline Month & Site Code & $\begin{array}{c}\text { Sighting } \\
\text { No. }\end{array}$ & $\begin{array}{c}\text { Number of } \\
\text { dolphin }\end{array}$ & $\begin{array}{c}\text { Total number } \\
\text { of dolphin }\end{array}$ & Mean group size \\
\hline \multirow{2}{*}{ Dec } & B3 & 4 & 2 & 7 & 1.75 \\
& C1 & & 2 & & \\
& C2 & & 1 & & \\
& C3 & & 2 & 6 & 1.5 \\
\hline
\end{tabular}




\begin{tabular}{|c|c|c|c|c|c|}
\hline Month & Site Code & $\begin{array}{l}\text { Sighting } \\
\text { No. }\end{array}$ & $\begin{array}{c}\text { Number of } \\
\text { dolphin }\end{array}$ & $\begin{array}{c}\text { Total number } \\
\text { of dolphin }\end{array}$ & Mean group size \\
\hline & $\mathrm{C} 1$ & & 1 & & \\
\hline & $\mathrm{C} 2$ & & 2 & & \\
\hline & C3 & & 2 & & \\
\hline \multirow[t]{4}{*}{ Feb } & B3 & 4 & 2 & 7 & 1.75 \\
\hline & $\mathrm{C} 1$ & & 1 & & \\
\hline & $\mathrm{C} 2$ & & 1 & & \\
\hline & $\mathrm{C} 3$ & & 3 & & \\
\hline \multirow[t]{4}{*}{ Mar } & B3 & 4 & 1 & 5 & 1.25 \\
\hline & $\mathrm{C} 1$ & & 1 & & \\
\hline & $\mathrm{C} 2$ & & 1 & & \\
\hline & $\mathrm{C} 3$ & & 2 & & \\
\hline \multirow[t]{2}{*}{ Apr } & $\mathrm{C} 1$ & 2 & 1 & 3 & 1.5 \\
\hline & $\mathrm{C} 3$ & & 2 & & \\
\hline \multirow[t]{3}{*}{ May } & $\mathrm{C} 1$ & 3 & 1 & 4 & 1.33 \\
\hline & $\mathrm{C} 2$ & & 1 & & \\
\hline & $\mathrm{C} 3$ & & 2 & & \\
\hline \multirow[t]{2}{*}{ Jun } & $\mathrm{C} 1$ & 2 & 1 & 2 & 1 \\
\hline & $\mathrm{C} 2$ & & 1 & & \\
\hline Jul & $\mathrm{C} 3$ & 1 & 1 & 1 & 1 \\
\hline Aug & - & 0 & 0 & 0 & 0 \\
\hline Sep & - & 0 & 0 & 0 & 0 \\
\hline \multirow[t]{5}{*}{ Oct } & B2 & 5 & 4 & 12 & 2.4 \\
\hline & B3 & & 2 & & \\
\hline & $\mathrm{C} 1$ & & 4 & & \\
\hline & $\mathrm{C} 2$ & & 1 & & \\
\hline & $\mathrm{C} 3$ & & 1 & & \\
\hline \multirow[t]{5}{*}{ Nov } & B2 & 5 & 1 & 14 & 2.8 \\
\hline & B3 & & 4 & & \\
\hline & $\mathrm{C} 1$ & & 5 & & \\
\hline & $\mathrm{C} 2$ & & 2 & & \\
\hline & $\mathrm{C} 3$ & & 2 & & \\
\hline
\end{tabular}


Furthermore, local fishermen informed about the less availability of fishes (number and diversity) and crustaceans also, which are the main food items for the Ganges River dolphins. In addition, threat to dolphins in the Buriganga river specially site B1 (Babu Bazar to Kholamora ghat). Hazaribagh channel is located very close in B1 site to the bank of Buriganga River. The Hazaribagh tannery is the most harmful among these, which disposes about $12,000 \mathrm{~m}^{3}$ of untreated wastes daily in the Buriganga (Biswas and Hamada 2012). Abundance estimation for dolphins in the Buriganga River are moderate, and absence of dolphins in some locations where previously existed indicate a cause for concern. Given these species' vulnerable conservation status globally, there is an urgent need of better understanding how these abundance estimates help conserve them.

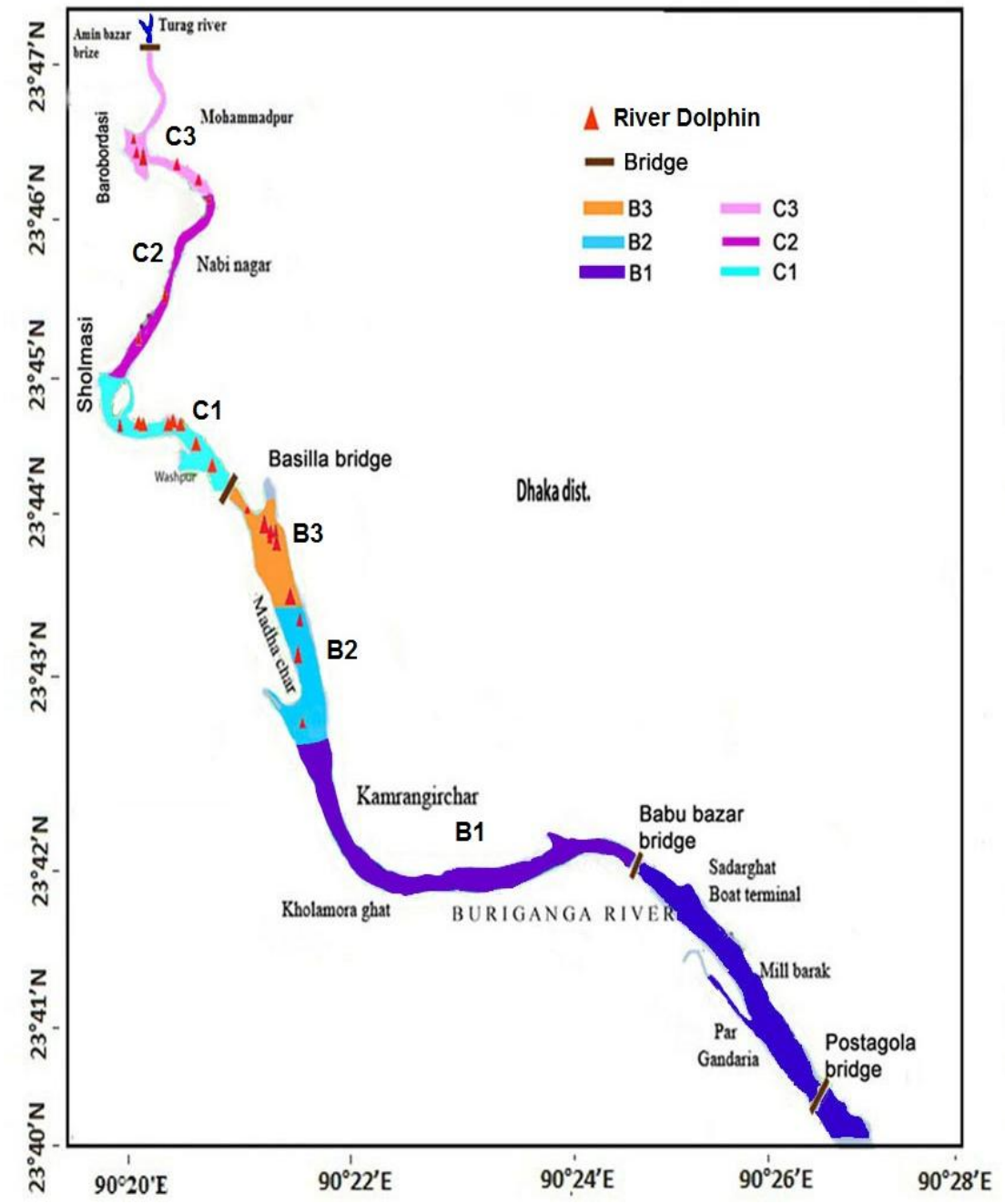

Fig. 4. Observed Ganges River Dolphins at different location in the Buriganga River. 
This issue needs to focus on a very small geographic area, relate to threats in the region, and to establish whether these small populations are genetically isolated or still in breeding contact with other neighbouring populations in the Buriganga River. Smith 1993 mentioned that river dolphins prefer particular channel reaches with counter-currents and deep pools. Wide single straight channel has connected in B2 site, Narrow single curve channel; wide single curve channel and floodplain have connected in B3, C1 and C3 site which can be linked to the dolphin for survived in the Buriganga River. The constant noise of vessel traffic might inhibit the ability of river dolphins to avoid collision with potential consequences (Smith 1998). We have seen them to avoid water vehicles in Basilla area of Buriganga River. Alam (2005) found that, on an average, a total of 188 vehicles crossed different points and another 1,270 vehicles remained standing that also ran through the river per hour.

During our study, we found that there are growing concerns for clean the Buriganga River among the public. Conservation of Ganges River Dolphins means ultimate conservation of this river and its biodiversity and this species can be used as a flagship species in this regard. Therefore, public awareness should be created on the role of dolphins in nature, pollution and its effects, environment legislations and importance of the clean Buriganga on socioeconomy.

Acknowledgement: This research work was funded by Jagannath University Grant for Research 2012-13. The authors would like to thank the students and the field assistants of the Department of Zoology, Jagannath University, Dhaka for helps during the field survey.

\section{LITERATURE CITED}

AHMED, A.U. and REAZUDDIN. 2000. Industrial Pollution of Water Systems in Bangladesh, University Press Limited, Dhaka, Bangladesh. pp. 175-178.

AHMED, B. 2000. Water Development and the Status of the Shushuk (Platanista gangetica) in Southeast Bangladesh, In: R. R. Reeves, B. D. Smith and T. Kasuya (eds.) Biology and Conservation of Fresh water Cetaceans in Asia. IUCN Species Survival Commission Occassional Paper 23. Gland. Switzerland and Cambridge, UK. pp. 62-66.

ALAM, M.S. and M.H. CHOWDHURY. 2012. River. $<$ http://www.banglapedia.org/HT/R_ 0264.htm> On-line version dated 28 January 2014.

ALAM, S.M.A. 2005. Status, Distribution and Conservation Issues of Ganges River Dolphin Platanista gangetica gangetica (Roxburgh,1801) in river Buriganga. (Unpublished thesis). Department of Zoology, The University of Dhaka.

ALAM, S.M.A. and N. SARKER 2012. Status and distribution of Gangetic dolphin, Platanista gangetica gangetica (Roxburgh, 1801) in river Buriganga during 20032004 and its conservation. Bangladesh J. Zool. 40(1): 21-31. 
ANDERSON, J. 1878. Anatomical and Zoological Researches Comprising an Account of the Two Expeditions to the Western Yunnan in 1868 and 1875 and a Monograph of the Cetacean Genera Platanista and Orcaella. Bernard Quaritch. London. pp. 500.

BANNERJEE, M. 1999. A report on the impact of Farakka barrage on the human fabric. Report. World Commission on Dams-Thematic Review. South Asia Network on Dams, Rivers and People, New Delhi.

BEGON, M., J.L. HARPER and C.R. TOWNSEND. 1996. Ecology - individuals, populations and communities. Oxford, UK: Blackwell Science.

BISWAS, B. and T. HAMADA. 2012. Relation between Hazaribagh Tannery Industry Development and Buriganga River Pollution in Bangladesh. International $\mathrm{J}$. Environment 2(2): 117-127.

CHAUDHARY, S. 2007.Status of, and Threats to, the Ganges River Dolphin (Platanistagangetica) in the Koshi River, Nepal. M.Sc. Thesis. Department of Economics, University of Klagenfurt, Austria, $\mathrm{x}+38 \mathrm{pp}$.

CITES 2013. CITES Appendices I, II and III. <http://www.cites.org/eng/app/2013/EAppendices-2013-06-12.pdf> Downloaded on January 11, 2014.

CMS 2012. Platanista gangetica (Roxburgh, 1801).<http://www.cms.int/reports/small_ cetaceans /data/P_gangetica/p_gangetica.PDF> Downloaded on January 11, 2014.

CULIK, B. 2003. Review on small cetaceans: distribution, behaviour, migration and threats. Compiled for CMS/UNEP. (available from CMS website).

DUDGEON, D. 2000a.The ecology of tropical Asian rivers and streams in relation to biodiversity conservation. Annual Review of Ecology and Systematics 31: 239-263.

DUDGEON, D. 2000b. Large-scale hydrological changes in tropical Asia: prospects for riverine biodiversity. Bioscience 50: 793-806.

DUDGEON, D. 2005. River rehabilitation for conservation of fish biodiversity in monsoonal Asia. Ecology and Society 10: 15-19.

DURDEN, W.N. 2005.The harmful effects of inadvertently conditioning a wild bottlenose dolphin (Tursiopstruncatus) to interact with fishing vessels in the Indian River Lagoon, Florida, USA. Aquatic Mammals, 31(4): 413-419. doi: 10.1578/AM.31.4.2005.413.

GERGEL, S. E., M. TURNER, J. MILLER, J. MELACK, AND E. H. STANLEY.2002.Landscape indicators of human impacts to riverine systems. Aquatic Science 64: 118-128.

GÓMEZ-SALAZAR, C. 2012. River Dolphins as Indicators of Ecosystem Degradation in Large Tropical Rivers. PhD Thesis. Dalhousie University, Halifax, Nova Scotia, Canada. http:// dalspace.library.dal.ca:8080/bitstream/handle/ 10222/ 14446/GomezSalazar,\%20 Catalina, \% 20PhD,\%20BIOL,\%20Mar\%202012.pdf?sequence $=1$.

HAQUE, A.K.M.A. 1976. Comments on the Abundance and Distribution of the Ganges susu, Platanistagangetica and the Effect of the Farrakka Barrage on its Population. ACMRR/MM/SC 132. Advisory Committee on Marine Resources Research, Scientific Consultation on Marine Mammals. FAO, Rome.

ISLAM, S.M. 2011. Land use Change Detection of the Buriganga River Using GIS Tools and its Water Management for Promoting a Sustainable Environment. TRITA-LWR 
Degree Project 11:13. Royal Institute of Technology (KTH). Stockholm, Sweden. http://kth.diva-portal.org/smash/ get/ diva 2:472907/FULLTEXT02.

JONES, S. 1982. The present status of the Gangeticsusu, Platanista gangetica (Roxburgh), with comments on the Indus susu, P. minor Owen. In: Mammals of the Seas. F.A.O. Fish. Ser. 5(4): 97-115.

IUCN Bangladesh. 2000. Red Book of Threatened Mammals of Bangladesh. IUCN- The World Conservation Union.xii $+71 \mathrm{pp}$.

IWM. 2004. Feasibility and Mathematical Model Study of Approaching and Investigating Strategy for Rehabilitating the Buriganga-Turag-Shitalakhya River System and Augmentation of Dry Season Flow in the Buriganga River, Feasibility Report. Bangladesh Water Development Board, Ministry of Water Resources, GoB.

KASUYA, T. and A.K.M.A. HAQUE. 1972. Some Information on the Distribution and Seasonal Movement of the Ganges Dolphin. Sci. Rep. Whales Res. Inst. Tokyo 24: 109-115.

KLINOWSKA, M. 1991.Dolphins, porpoises and whales of the world: The IUCN red data book. Gland, Switzerland and Cambridge, UK: IUCN. 429 pp.

MANEL, S., S.T. BUCKTON, and S.J. ORMEROD. 2000. Testing large-scale hypotheses using surveys: The effects of land use on the habitats, invertebrates and birds of the Himalayan rivers. Journal of Applied Ecology 37: 756-770.

MARTA J.C., A.S. FERNANDO, A.J.T. HARDT, JR. and P.C. SIMÕES-LOPES 2011. Distribution and status of the Guiana dolphin Sotaliaguianensis (Cetacea, Delphinidae) population in Babitonga Bay, southern Brazil. Zoological Studies 50(3): 327-337.

MOHAN, R.S.L. 1989. Conservation and Management of the Ganges River dolphin, Platanista gangetica, in india. In: Biology and conservation of the river dolphins, occasional papers of the IUCN Species Survival Commission, No. 3. Edited by W.F. Perrin, R.L. Brownell, K. Zhou and J. Liu, IUCN, Gland, Switzerland. pp. 64-69.

PAYNE, A. I., and S.A. TEMPLE. 1996. River and floodplain fisheries in the Ganges basin. Final report R.5485. Marine Resources Assessment Group Limited, Overseas Development Administration, London

REEVES, R.R. and R.L. BROWNELL 1989. Susu - Platanista gangetica (Roxburgh, 1801) and Platanista minor Owen, 1853. In: Handbook of Marine Mammals (Ridgway SH, Harrison SR eds.) Vol. 4: River Dolphins and the Larger Toothed Whales. Academic Pres, London, pp. 69 - 100.

REEVES, R.R., B.D. SMITH AND T. KASUYA (EDS.). 2000. Biology and Conservation of Freshwater Cetaceans in Asia. IUCN, Gland, Switzerland and Cambridge, UK.viii + $152 \mathrm{pp}$.

REEVES, R.R., LEATHERWOOD, S. and MOHAN, R.S.L. 1993. A future for Asian river dolphins: Report from a seminar on the conservation of river dolphins of the Indian Subcontinent, 18-19 August 1992, New Delhi, India. Whale and Dolphin Conservation Society, Bath, England.

SHRESTHA, T.K. 1989. Biology, status and conservation of the Ganges river dolphin, Platanistagangetica, in Nepal, pp. 70-76. In: Perrin, W.F., R.L. Brownell, Jr., Z. Kaiya\& L. Jiankang (eds.). Biology and Conservation of The River Dolphins. 
Occasional papers of the IUCN Species Survival Commission No. 3, IUCN, Gland, Switzerland.

SINHA, R.K. and G. SHARMA 2003. Current status of the Ganges river dolphin in the rivers Koshi and Son.Journal of the Bombay Natural History Society 100(1): 27-37.

SINHA, R.K. 2006. The Ganges river dolphin Platanista gangetica. Journal of the Bombay Natural History Society 103: 254-263.

SMITH B., A. HAQUE, M.S. HOSSAIN and A. KHAN. 1998. River dolphins in Bangladesh: conservation and the effects of water development. Environmental Management 22:323-335.

SMITH B., G. BRAULIK, S. STRINDBERG, B. AHMED and R. MANSUR. 2006. Abundance of Irrawaddy dolphins (Orcaella brevirostris) and Ganges river dolphins (Platanista gangetica gangetica) estimated using concurrent counts made by independent teams in waterways of the Sundarbans mangrove forest in Bangladesh. Marine Mammal Science 22: 527-547.

SMITH, A.M. and B.D. SMITH. 1998. Review of Status and Threats to River Cetaceans and Recommendations for their Conservation. Environ. Rev.6: 189-206.

SMITH, B., R. SINHA, U. REGMI and K. SAPKOTA. 1994. Status of Ganges river dolphins (Platanista gangetica) in the Karnali, Mahakali, Narayani and SaptaKosi Rivers of Nepal and India in 1993. Marine Mammal Science 10: 368-375.

SMITH, B.D. 1993.1990 status and conservation of the Ganges River dolphin Platanista gangetica in the Karnali River, Nepal. Biol. Conserv. 66(3): 159-169.

SMITH, B.D., AHMED, B., ALI, M. E. AND BRAULIK, G. 2001. Status of Ganges River Dolphin or Shushuk Platanista gangeticain Kaptai Lake and Southern Rivers of Bangladesh. Oryx 35(1): 61-72

SMITH, B.D., G.T. BRAULIK and R. SINHA. 2012. Platanista gangetica ssp. gangetica. In: IUCN 2013.IUCN Red List of Threatened Species. Version 2013.2.<www.iucnredlist.org>. Downloaded on 11 January 2014.

WAKID, A. and G. BRAULIK. 2009. Protection of endangered Gangetic dolphin in Brahmaputra River, Assam, India. Final report to IUCN-Sir Peter Scott Fund. pp. 44. 